\title{
Putting the Third Wave into Practice: Democracy Promotion in Kenya
}

John W. Harbeson

\begin{abstract}
Joel Barkan's work as the U.S. Agency for International Development's Regional Democracy and Governance Advisor for Eastern and Southern Africa brought both realism and conceptual strengthening to democracy promotion, most notably giving legitimacy and practical meaning to the concept of civil society as an essential dimension of democratization.
\end{abstract}

Résumé: Le travail de Joel Barkan à l'organisation internationale de développement démocratique régionale et conseiller en gouvernance pour l'Afrique de l'est et du sud a apporté réalisme et renforcement conceptuel à la promotion de la démocratie, notamment en donnant légitimité et sens pratique au concept de la société civile comme une dimension essentielle à la démocratisation.

Keywords: Democratization; civil society; USAID; Kenya

When democracy's Third Wave first came to sub-Saharan Africa, Joel Barkan was one of a small community of academic political scientists who had the remarkable opportunity to serve as Democracy and Governance Advisors in United States Agency for International Development (USAID) missions

African Studies Review, Volume 59, Number 3 (December 2016), pp. 129-137

John W. Harbeson is an emeritus professor of political science at the City University of New York and a professorial lecturer at the Johns Hopkins University School of Advanced International Studies and the Elliott School of International Affairs of George Washington University. He is the author of numerous books and articles and most recently the co-editor of Africa in World Politics: Engaging a Changing Global Order (Westview Press, 2013). He was USAID's Regional Democracy and Governance Advisor for Eastern and Southern Africa from 1993 to 1995. E-mail: jwharbeson@aol.com 
in sub-Saharan Africa. ${ }^{1}$ That opportunity occurred because for a very few years USAID found itself without trained democracy promotion officers when democracy's Third Wave reached Africa's shores not long after the end of the Cold War. ${ }^{2}$ Joel Barkan and I served as Regional Democracy and Governance Advisors in USAID's Regional Economic Development Service Office for Eastern and Southern Africa (REDSO) based in Nairobi. We were in effect in-house contractors, but for most purposes we worked on the same terms as career USAID personnel. The end of his two-year assignment (1992-94) and the beginning of mine (1993-95) overlapped for six months in late 1993 and early 1994, during which time we collaborated in working with the USAID Kenya and REDSO missions in their engagements with governments to promote, on the ground, the broad objectives of Third Wave Democracy.

This short article centers on Joel Barkan's work as USAID's Regional Democracy and Governance Advisor to engage its bilateral and regional missions based in Kenya in promoting that country's further democratization. As this special forum makes clear, Joel Barkan's engagement with democracy promotion ranged widely, both geographically and topically. But the epicenter of his work throughout his career was in and on Kenya, especially during these two years when he worked in USAID/REDSO. The particular challenge then was the Paris Club's decision that continued development assistance to the country would be based on the condition that President Moi permit an amendment to the constitution, long barnacled with authoritarian provisions, that permitted competitive multiparty elections. The historic elections that followed, in December 1992, were flawed by corruption and violence. But as this forum also makes clear, then and for long afterward, the government and people of Kenya, and the country's many friends, have been much the better for Barkan's work in support of democratic governance.

\section{The Eastern and Southern African Context}

The mighty challenge to democracy promotion that Kenya posed, and continues to pose, is best understood by, first, reviewing the context in which its achievements and shortcomings occurred, and then considering the challenges facing USAID in promoting democracy. From the perspective of the present, and with the benefit of hindsight, the 1990s in sub-Saharan Africa were evanescent, halcyon years for democracy promotion, for at least two important reasons. On the one hand, democracy promotion enjoyed international support in the forms of technical assistance and modest financial support from aid agencies, reflecting a purposefulness for a time relatively undiminished by other, conflicting major power priorities on the continent. At the same time, human rights and democracy advocacy groups generated significant, albeit clearly varied and differential, degrees of democratic momentum throughout the more than twenty countries of the eastern and southern Africa region. But subsequently, after the first years of the 
new century, even as most of the continent has entered a period of unprecedented and fairly robust economic growth, that halcyon democratic moment has clearly ebbed. This loss of momentum has been a casualty of (1) the limited effectiveness of electoral democracy alone to arrest and reverse profound state weakness, previously partially masked by aggressively authoritarian ruling regimes, ${ }^{3}$ (2) an international order whose major players have become preoccupied with countering global terrorism, and (3) African regimes that have found ways to conduct passable multiparty elections while still retaining dimensions of corrupt and undemocratic rule. Democratic retreats and loss of democratic momentum have been particularly visible in Freedom House assessments, which have shown steady, if gradual, democratic slippage since about $2005 .{ }^{4}$

This ephemeral juxtaposition of vibrant domestic pressure for political liberalization and strong external support for democratic initiatives was indispensible to the production of sub-Saharan Africa's post-Cold War democratization. No longer needed in support of Cold War alliances, authoritarian regimes, notably the South African apartheid regime, lost much of their bilateral international support over the following decade or so. During this decade, the first significant and in many cases unprecedented multiparty, relatively free and fair democratic elections took place in eastern and southern Africa. These early elections were especially notable because in Zambia (1991) and Malawi (1994) they displaced long-time rulers who had led their independence movements but who had become increasingly authoritarian. They were pathbreaking in Kenya (1992), where the Paris Club, responding to protests over egregious human rights abuses, demanded that an authoritarian President Moi enact constitutional change to permit multiparty elections as a condition for its continued development support. In Mozambique in 1994, with the benefit of large-scale external assistance, the country's first democratic, remarkably free and fair multiparty elections marked the conclusion of a civil war that had lasted since the country's independence in 1975. And in Namibia (1989) and South Africa (1994), democratic elections heralded the end of the apartheid era. These electoral transitions created the beginnings of a democratic neighborhood for Botswana and Mauritius, for a quarter of a century lonely outposts of certifiable democracy on the continent.

Late Cold War-era transitions in southern Europe and Latin America as well as those in eastern and central Europe that emerged in the wake of the Soviet Union's collapse may have done as much as some of the early academic literature on these democratic openings to fuel teleological expectations that embryonic sub-Saharan democratic transitions would predictably establish deep constitutional roots and suffuse governmental structures broadly. As with similar teleological thinking implicit in independence-era modernization theory which anticipated and implicitly predicted flourishing socioeconomic development and eventual democracy in African and other developing countries, stubborn realities have tended to prevail in the form of authoritarian rule, corruption, and political instability. Now, in the 
second decade of the twenty-first century, no contagious spread of democratic movements has accompanied these early remarkable transitions in eastern and southern Africa. In particular, while perhaps a dozen subSaharan African countries have sustained still fragile but significant democratic rule, expectations of more enlightened political leadership from a new generation of African leaders elsewhere were largely and promptly dashed by the genocide in Rwanda and abrupt termination of democratic momentum by Issayas Afewerki in Eritrea following its successful secession from Ethiopia. Meanwhile, in Ethiopia, Meles Zenawi's innovative ethnic confederal constitutional formula for rescuing the country from further secessionist movements produced no democracy and only qualified governmental devolution. Yoweri's Museveni's "no party" democracy model restored some measure of national unity in Uganda but yielded only flawed, limited democracy. Elsewhere, Mugabe's Zimbabwe became and has remained only more authoritarian, Swaziland's monarchy remains in place, Lesotho experienced a semblance of democratic stability with the benefit of SADC's intervention, and the collapsed state of Somalia is only today, at best, in the first fragile stages of potentially democratic rehabilitation.

\section{Democracy Promotion in Kenya}

At least within eastern and southern Africa, Kenya has inhabited a place in the middle of the spectrum between the most successful post-Cold War democracies-plausibly, South Africa and Namibia-and the manifest failures of democracy in the countries of the Horn of Africa, with Djibouti a partial exception. Thus, in the estimation of Freedom House, Kenya has remained only a partially free country ever since its initial competitive multiparty elections in1992, the country's first since just before its independence in 1963. On the one hand, a courageous and vocal community of human rights activists brutalized by the regime of President Daniel arap Moi managed to capture the attention of the Paris Club, resulting in the 1992 multiparty elections and becoming the foundation of vibrant civil society advocacy for comprehensive constitutional reform, finally achieved only in 2010. On the other hand, even the eventual formulation and passage of this model constitution has been insufficient to unravel many of the layers of corruption and authoritarian rule that have accumulated since independence and even earlier, dispelling early expectations that political liberalization would bring about transformative results.

USAID's challenge in the years following the first multiparty elections in 1992, therefore, was to try to fashion initiatives that would infuse elements of democracy into Kenya's political order that the national elections heralded but did not themselves accomplish or make inevitable. As REDSO's Regional Democracy and Governance Advisor, Joel Barkan was a key player in this effort. He was asked to draw upon his then quarter-century of research, teaching, and networking in Kenya and East Africa. In so doing, 
he could draw upon rich precedents in the history of political philosophy. Nonetheless, the challenge of operationalizing these venerable democratic concepts to achieve existential democratic advancement on the ground in newly democratizing countries, at the time, was well outside mainstream academic political science.

Barkan's challenge in doing so, and mine as his successor, was complicated by several additional factors that were not within his control. First, in contrast to democratic transition processes, particularly in several southern Africa countries, international actors collectively did not engage the government of Kenya in attempting to achieve full constitutional reform prior to the mandated multiparty elections. This choice tended to leave all major dimensions of democratization, other than achieving free and fair elections, to subsequent trench-by-trench institutional reform efforts with the assistance of USAID and other predominantly bilateral donors. ${ }^{5}$

Second, USAID's culture itself presented obstacles to its engagement in promoting aspects of democratic reform, because many of its officers had traditionally thought of the agency's development assistance initiatives as being apolitical, and they were more comfortable, in any event, with a focus on economic development projects. Third, notwithstanding the actions of Smith Hempstone, the U.S ambassador to Kenya during Barkan's USAID tour whose jousting with the Moi administration over its still deeply flawed human rights observance earned him the lasting affection of a great many Kenyans, U.S. foreign policy priorities in the country continued quietly to emphasize retention of Cold War-era access rights to military bases, which required the cooperation of the Moi government. ${ }^{6}$

For the first five years following the 1992 elections, USAID evolved a multifaceted assistance project that prioritized addressing key dimensions of Kenya's postelection democratization challenges. All of the components of this project were developed in collaboration with host country democracy advocates who, I think it is fair to say, envisaged them as steps toward achieving comprehensive constitutional reform, which they came to believe should have preceded the elections, given the Moi administration's resistance to them. To begin with, the serious political violence that marked the 1992 elections reflected a controversy over the foundation of the postindependence state that had been suppressed and unmediated since before independence: that is, to what extent the creation of a single countrywide market in land based on individual freehold tenure, thereby enabling Kenyans of all ethnic communities to farm any place in the country, should have been allowed to dissolve rural colonial-era ethnic enclaves. Smaller ethnic communities in particular displayed deep resentment of the presence of significant numbers of members of larger, more politically powerful ethnic communities in their traditional preserves. Kenya's deteriorating economy and the negative effects of multilaterally imposed structural adjustment programs also contributed to the violence. President Moi helped make his prediction that competitive multiparty elections would lead to ethnic violence become self-fulfilling by organizing the Kenya 
African National Union's (KANU) youth wing to instigate that violence. These unresolved land issues, exacerbated by police corruption and violence, would animate much of the ethnic violence, which persisted and exploded a decade and a half later during the contested 2007-2008 elections. These issues remain unresolved today notwithstanding a far-sighted reform policy passed by Parliament in 2009, the principles of which were written into the long-sought 2010 Constitution. The violence attending the 1997 elections, by contrast, had relatively more to do with failure to make progress toward that constitution, attributable also to a lack of cohesion among those advocating for it as well to Moi regime opposition.

The components of the USAID program that Joel Barkan and I worked to get approved and implemented over the course of our overlapping tours included establishing the Institute for Policy Analysis and Research (IPAR), supporting Kenyan nongovernmental organizations advocating for the advancement of human rights and democratization with constitutional reform as the ultimate objective, supporting the training of parliamentarians and the institutional strengthening of Parliament itself, and strengthening financial management in key Kenyan ministries. Beyond project development for democracy support, we represented USAID in a group of several principally European bilateral donor agencies, chaired by Canada, which concentrated in particular on monitoring parliamentary by-elections, sorting out the causes of the 1992 electoral violence, and considering possible cooperative ventures to prepare for the general elections in 1997. Joel, I, and others also served as Personal Services Contractors (PSCs) because USAID lacked in-house expertise on democracy promotion, although the agency quickly remedied this shortcoming and now has a cadre of officers specializing in this area.

IPAR continues as an independent think tank two decades later, along with the semi-official Kenya Institute for Policy Research and Analysis (KIPPRA). Support for strengthening sub-Saharan African parliaments has grown, spearheaded by the work of the State University of New YorkAlbany. In 2009 Barkan edited Legislative Power in Emerging African Democracies and was a principal collaborator in a larger, ongoing project monitoring African legislative behavior, as described by others in this ASR forum. USAID continues to support civil society development at a time when an initiative is afoot in Kenya to limit the independence of nongovernmental organizations and when civil society has been effectively suppressed in neighboring Ethiopia.

With the prominent exception of the U.S. government's Comprehensive Anti-Apartheid Act of 1986, which made possible funding for a very wide array of human rights advocacy organizations working to unravel apartheid in South Africa, the USAID project broke new ground in proposing to support civil society organizations in Kenya seeking to advance the country's democratization. Each of the project's other main components was supportable as institutional capacity building and thus represented a wellestablished and familiar USAID priority. Indeed, the financial management 
component was included to the discomfort of those not wishing to strengthen the capacity of an authoritarian regime, at the behest of those uncomfortable with the political agenda implicit in the other components. At the same time, the institutional strengthening purposes implicit in both the IPAR and Parliament components made their evident democracyadvancing agendas seem less threatening to the government, and indeed, to some within USAID itself. IPAR would foster African analytical capacity for independent policy analysis that would enhance the openness and transparency of policy debate in governmental and political circles. Parliamentary strengthening was essential to overcome and counterbalance the essentially unfettered and abusive executive dominance that had continued largely unchanged from the era of colonial governors.

Inclusion of a civil society component in the Kenya democracy project was contentious because (1) it forced reform of USAID policies and cultures, as the other component did not, (2) it conferred legitimacy on a societal sector of autonomous advocacy and societal engagement, and (3) it spurred academic debate about the extent to which, notwithstanding its philosophical and practical importance in the evolution of European democracy, it could legitimately "travel" to play a similar role in sub-Saharan African political liberalization. On the one hand, it obliged USAID to assume financial and to some extent legal risk because these fledgling advocacy organizations lacked the institutional capacity needed to be able to guarantee that they could meet USAID financial accountability requirements without assistance for that specific purpose. On the other hand, USAID was troubled about supporting civil society directly, bypassing the Ministry of Finance, because the direct support of nongovernmental organizations to strengthen political advocacy to advance democracy unambiguously challenged the USAID culture of apolitical development assistance. The effort to overcome these obstacles would achieve success worldwide within a few short years, as well as in Kenya, for civil society funding became and has remained an enduring constant of USAID democracy assistance.

Kenya's experience at this time and since has demonstrated that in order to be effective, external assistance for civil society democratic advocacy requires not just resource transfers, but also active, sustained hands-on engagement with civil society actors themselves. It is here, as well as with his many publications and work within USAID itself, that Joel Barkan arguably made his most critically important and enduring contributions to Kenya's democracy. Through friendship, counsel, and collaboration with a vast array of Kenyans in all walks of life-fellow academics, nongovernmental organization officials, legislators, media leaders, and others-he was a partner in their shared work to institutionalize democratic advocacy in civil society. This was his unique gift, throughout his career, but it was also one that at the time only someone who was "in," but not "of," USAID could easily undertake. More generally, Joel Barkan may have established the understanding that this personal, international partnership is a sine qua non for long-term democratic deepening and sustainability. 
Joel Barkan's personal diplomacy in advancing Kenyan civil society at a critical, vulnerable point in its evolution has supplied a unique and invaluable perspective on the academic debate on the role of civil society in the democratization of developing countries. That civil society has become a staple of bilateral and multilateral democracy assistance in later years has effectively mooted the argument that the phenomenon was unique to the circumstances of early modern Europe. His engagement with civil society democracy advocacy at a crucial early stage in Kenya's political liberalization supplied an empirical basis for countering academic critics who questioned the validity of civil society that was fledgling rather than fully formed and that relied in part on external nurture.

Joel Barkan's seamless blending of practitioner democratic advocacy and astute scholarship on Kenya's political life was among the most significant of his many accomplishments in a long and distinguished career. ${ }^{7}$ Kenyan democracy, USAID and bilateral assistance agencies more generally, and the political science profession have been the fortunate beneficiaries of this legacy.

\section{References}

Barkan, Joel. 1993 "Lessons from a Flawed Election.” Journal of Democracy 4 (3): 85-89.

- 1997. "Can Established Democracies Nurture Democracies Abroad." In Democracy's Victory and Crisis, edited by Axel Hadenius, 371-403. Cambridge, U.K.: Cambridge University Press.

Barken, Joel D., ed. 2009. Legislative Power in Emerging African Democracies. Boulder, Colo.: Lynne Rienner.

Harbeson, John. 1997 "Rethinking Democratic Transitions: Lessons from Eastern and Southern Africa." In State, Conflict and Democracy in Africa, edited by Richard Joseph, 39-56. Boulder, Colo.: Lynne Rienner.

Hempstone, Smith. 1997. Rogue Ambassador: An Africa Memoir. Sewanee, Tenn.: University of the South Press.

Huntington, Samuel. 1991. The Third Wave: Democratization in the Late Twentieth Century. Norman: University of Oklahoma Press.

\section{Notes}

1. The term "Third Wave" was coined by Samuel Huntington (1991) to examine the problem of democratic transitions that occurred in southern Europe and Latin America, and, with the end of the Cold War, in eastern and Central Europe. Noting that previous waves in the nineteenth and twentieth centuries had been followed by periods of democratic reversal, Huntington focused on models and processes for sustaining these latest transitions.

2. Other academics in that group (in addition to Joel Barkan and me) included Michael Turner (Mozambique), Rene Lemarchand (West Africa), James Polhemus (Zambia, and later Ethiopia), and Stevens Tucker (Ethiopia).

3. The term "electoral democracy," particularly as employed by Freedom House, has been defined as a minimum level of political rights, including some degree 
of electoral freedom and fairness, as distinct from more copious arrays for civil as well as political rights.

4. These assessments can be found at http://www.freeedomhouse.org.

5. I argued at the time that more comprehensive political reform, with the benefit of sustained international engagement, before initial competitive, multiparty elections, was a critical factor distinguishing countries exhibiting greater initial democratic progress from those with weaker, more compromised democratic starts. See Harbeson (1997).

6. See Hempstone (1997) for the ambassador's own account of his engagement with the Moi regime.

7. Among his many publications in this vein are Barkan (1993) and Barkan (1997). 